\title{
Teoria conflitual da política de Maquiavel: alternativa ao paradoxo moderno da relação entre poder constituinte e poder constituído?
}

La théorie conflictuelle de la politique de Machiavel: une alternative au paradoxe moderne de la relation entre pouvoir constituant et pouvoir constitué?

\section{José Luiz Ames}

Universidade Estadual do Oeste do Paraná | Paraná | Brasil

\section{RESUMO}

Maquiavel costuma não ser considerado nas reconstruçōes e debates teóricos acerca do problema da relação entre poder constituinte e poder constituído. Muito embora não seja um filósofo jurídico, buscaremos mostrar que sua teoria conflitual da política oferece uma contribuição singular para este paradoxo moderno ao considerar que a oposição dos humores de grandes e povo abre a possibilidade da coexistência dos momentos instituinte e instituído, isto é, dos momentos factual/político e normativo/jurídico. Nosso propósito será mostrar que, para Maquiavel, o povo exerce um papel "instituinte” do comando político em relação ao poder "instituído" quando se manifesta, seja por assembleias e instituiçóes como a dos Tribunos e da Acusação Pública na Roma republicana, seja pelas formas espontâneas do "barulho e da gritaria" nascidas dos tumultos; contudo, o exercício concreto do "poder instituído" permanece sempre fora da esfera de ação direta do povo.

\section{PALAVRAS-CHAVE}

Maquiavel; Conflito;

Poder constituinte; Poder constituído.

\section{RÉSUMÉ}

La pensée de Machiavel n'est généralement pas prise en compte dans la reconstruction et dans les débats théoriques sur le problème de la relation entre le pouvoir constituant et le pouvoir constitué. Bien qu'il ne soit pas un philosophe du droit, nous cherchons à montrer que sa théorie conflictuelle de la politique offre une contribution unique à ce paradoxe moderne lorsque l'on considère que l'opposition des humeurs des grands et du peuple ouvre la possibilité d'une coexistence entre le moment instituant et le moment institué, c'est-à-dire entre les moments factuel/politique et normatif/juridique. Notre but sera de montrer que le peuple, chez Machiavel, joue un rôle " instituante " du commandement politique par rapport au pouvoir " institué » lorsqu'il se manifeste, soit dans les assemblées et des institutions comme les Tribuns et L'accusation publique dans la Rome républicaine, soit par des formes spontanées de " bruit et des cris » nées des émeutes. Cependant, l'exercice effectif du " pouvoir institué » reste toujours en dehors de la sphère d'action directe du peuple.

\section{MOTS CLEFS}

Machiavel; Conflit;

Pouvoir constituant; Pouvoir constitué. 


\section{Colocação do problema}

Poder constituinte é um conceito moderno. É bem verdade que suas origens podem ser remetidas ao pensamento medieval, mas emerge da forma como o concebe a filosofia política e jurídica atual somente com a criação do Estado como figura abstrata e impessoal, cuja invenção mais acabada pode-se remeter a Thomas Hobbes. Para fundamentar a legitimidade da soberania estatal, Hobbes recorre ao contrato de autorização por meio do qual os indivíduos assumem uma obrigação recíproca comprometendo-se a reconhecer as açōes e palavras de uma pessoa (no sentido jurídico de ser um indivíduo ou grupo de indivíduos) como expressóes da própria vontade. Assim, uma vez recebida a autoridade de representar a vontade de qualquer outro, o representante (o soberano) obriga com suas palavras e ações ao representado (a multidão convertida em povo ao instituir o soberano). A formulação hobbesiana do fundamento da legitimidade da autoridade soberana dá origem a uma linha de pensamento que funda uma distinção essencial entre "poder constituído" (o poder exercido pelo soberano para governar) e "poder constituinte" (o poder do povo por meio do qual o poder de governar do soberano foi autorizado).

Esta tradição de pensamento iniciada com Hobbes faz-nos deparar com o paradoxo acerca da origem da esfera jurídica e da relação entre os momentos constituinte e constituído. Para sua fundação, o direito positivo tem necessidade de um poder extralegal e normativo. Esse poder, porém, é factual e político e não tem outra força do que a força com a qual estabeleceu para si mesmo (e a percepção nas democracias contemporâneas parece ser de que o estabeleceu contra) o poder constituído. Além disso, uma vez estabelecido e reconhecido, o poder soberano não pode tolerar a existência de sua fonte (o poder constituinte popular), porque precisa ser a única fonte de legitimidade.

Maquiavel costuma não ser considerado nas reconstruções e debates teóricos acerca deste problema. Muito embora não seja um filósofo jurídico, entendemos que sua teoria conflitual da política oferece uma contribuição singular no sentido de propor uma alternativa teórica ao paradoxo moderno acima referido. Esta alternativa, pensamos, pode ser visualizada na teoria do conflito civil decorrente da oposição dos humores de grandes e povo. Nosso propósito será o de mostrar que a "teoria dos humores" de Maquiavel permite pensar a possibilidade da coexistência dos momentos instituinte e instituído ${ }^{\mathrm{I}}$, dos momentos factual/

I "Poder constituinte", como conceito referido ao pensamento de Maquiavel, pode levantar, com razão, a observação, entre outras, de que se trata de um anacronismo. Muito embora Maquiavel se utilize do termo costituzioni (sempre no plural) ao menos em três passagens distintas (O Príncipe vi:23; xıx:20; Discursos I, 45:9), é verdade que nelas não contempla ainda o significado que este termo adquiriu na contemporaneidade, de documento escrito 
político e normativo/jurídico. ${ }^{2}$

A hipótese que levantamos é, pois, de que em Maquiavel se faz presente uma forma diferente de conceber o povo do que este o será na modernidade, ou seja, nem como multidão dispersa (como Hobbes), nem como algo já constituído, como um corpo com identidade definida como na tradição. Nestas duas modalidades o poder constituido "representa" o povo no sentido de alguém que "toma o lugar de" e "age em seu nome". A hipótese que avançamos é de que, para Maquiavel, o povo está, ao mesmo tempo, "presente" e "ausente" das estruturas do poder instituído. Está presente, uma vez que as leggi et ordini que regem o poder instituído são o resultado da dinâmica de confronto/encontro entre grandes e povo; está ausente, porque o povo está fora do exercício direto do comando político e, nesse sentido, é a instância crítica que mantém ativa a historicidade do poder instituído. Assim, pretendemos mostrar que, para Maquiavel, o povo exerce o "papel instituinte" do comando político quando se manifesta, seja por instituições como a dos Tribunos da plebe e da Acusação Pública na Roma republicana, seja pelas formas espontâneas do "barulho e da gritaria" nascidas dos tumultos. Estes mecanismos institucionais "representam" o povo não no sentido de um terceiro como em Hobbes, mas no sentido de ser o próprio povo em ação. No entanto, o exercício concreto do comando político permanece sempre fora da esfera de ação do povo.

reunindo em fórmulas definitivas a lei fundamental que rege o Estado. Seja como for, o exame das passagens nas quais Maquiavel se refere a costituzioni (e levando em conta igualmente o uso que faz de ordini e leggi), permite-nos associar o termo ao significado jurídico-político daquilo que está “instituído". Em relação ao significado ocupado pelos conceitos ordini e leggi no pensamento maquiaveliano, Ercole, por exemplo, chega a afirmar que "correspondem normalmente, na linguagem de Maquiavel, àquilo que chamamos constituição ou organização jurídica e política do Estado, ainda mais quando se unem ordini e leggi, como em uma única concepção" (Ercole, I929, apud De Vries, I957, p. I8). Hans De Vries, após a análise da "linguagem constitucional” na obra de Maquiavel, concluiu que o termo costituzioni, "possui ainda sua significação passiva do que está constituído, o que pressupóe a existência de um 'constituinte”" (De Vries, I957, p. 9). Atentos a esta conclusão do estudioso holandês, nos referiremos a um "momento instituinte" e a um "momento instituído" no processo de criação do aparato jurídicopolítico em Maquiavel como par conceitual precursor do que na modernidade se entenderá por "poder constituinte" e "poder constituído", respectivamente.

2 Cabe ressaltar que esta tentativa não é nova. Entre os trabalhos que apontam na mesma direção destacamos os seguintes: Filippo Del Lucchese, "Machiavelli and constituent power: The revolutionary foundation of modern political thought", European Journal of Political Theory, 20I4, pp. I-2I; Antonio Negri, O poder constituinte - Ensaio sobre as alternativas da modernidade, Rio de Janeiro: DP\&A, 2002; Miguel Vatter, "Legality and resistance: Arendt and Negri on constituent power", Kairos, n. 20, 2002, pp. 19I-230; John McCormick, "People and elites in republican constitutions", In Martin Loughlin e Neil Walker (Eds). The paradox of constitutionalism: constituent power and constitutional form, Oxford: Oxford University Press, 2007. 


\section{0 conflito dos humores}

As sociedades políticas, argumenta Maquiavel, são marcadas pela oposição entre dois desejos (ou humores): o de dominar (próprio aos grandes) e o de não ser dominado (característico do povo). ${ }^{3}$ A relação entre grandes e povo se caracteriza, primeiramente, como impossível de ser completada e, em segundo lugar, como impossível de ser composta, de haver um acordo, constituindo-se, como afirma Lefort (1972, p. 382), em "uma oposição constitutiva do político".

O que faz com que o conflito seja insuperável, ou "constitutivo do político"? Não é por se tratar, explica Lefort (1972, p. 382), "de uma distinção de fato, pois aquilo que faz com que os grandes sejam grandes e que o povo seja povo, não é que tenham por sua fortuna, por seus costumes, ou por sua função um estatuto distinto associado a interesses específicos e divergentes". Igualmente não é porque seria algo que devesse ser remetido à "natureza" - como poderíamos ser induzidos a pensar em virtude de Maquiavel falar em oposição de "desejos" ou de "humores". ${ }^{4}$ Ainda que se trate de uma pulsão propriamente humana — desejo ou humor — não é a natureza o que torna impossível sua conciliação. Com efeito, quando Maquiavel caracteriza a oposição constitutiva da política como fundada em humores ou desejos, toma estes termos não na sua acepção antropológica - como em Hobbes, por exemplo — , e sim no sentido de metáforas do corpo político. Devemos a Marie Gaille-Nikodimov o estudo mais consistente que afasta o uso dos termos "desejo" e "humores" por Maquiavel do seu significado antropológico:

O cidadão jamais é visado como um indivíduo, mas apreendido nas associações, nos grupos, definidos por uma unidade de comportamento e de interesse; a cidade não é concebida como um todo composto de partes, mas como um conjunto de fronteiras instáveis, mutáveis e evolutivas. A fim de descrever isto, Maquiavel se inspira nas concepçôes médicas antigas: a cidade é para ele um "corpo misto" composto de elementos definidos pela relação dinâmica que mantêm entre si, os "humores" (Gaille-Nikodimov, 2004, p. 9).

Contudo, é preciso ressaltar que não é um acaso que Maquiavel se utilize do

3 Cf. Príncipe Ix; Discursos I, 4; História de Florença II, I2.

4 Com efeito, e para reforçar esta impressão, em uma passagem muito significativa Maquiavel parece enfatizar esta característica "antropológica" do desejo: "A natureza criou os homens de tal modo que eles podem desejar qualquer coisa, mas não podem obter qualquer coisa, de modo que, sendo sempre maior o desejo que a potência de conquistar, resulta disso o descontentamento e a pouca satisfação em relação a isso" (Discursos, I,37:4). 
termo umori (ou desideri, termo que ele emprega em sentido equivalente àquele) para se referir à oposição fundamental das cidades. Como explica Sfez (I999, p. 188), "a noção de diversidade de humores implica necessariamente que a cidade não é a soma ou a retomada num todo de seus humores". Isso nos leva a compreender porque não é possível o acordo entre as partes — grandes e povo. Estas, ao contrário do que defende Aristóteles, não representam partes de um todo (da cidade/polis). Para Maquiavel, argumenta Sfez (1999, p. I89), "nenhum humor exprime um ponto de vista incompleto porque não existe o todo do Estado".

O que temos, portanto, é um enfrentamento de duas forças sociais fundado em dois projetos políticos opostos os quais cindem a cidade de modo radical. O que torna assimétrica esta relação é a diferença de posição dos atores em confronto, ou seja, de "comandar" da parte dos grandes e de "não ser comandado" da parte do povo. Assim, a acumulação de meios de opressão para serem exercidos sobre o povo por parte dos grandes encontra no povo uma busca correspondente (mas não necessariamente equivalente) de meios de resistência no sentido de conter a opressão. $\mathrm{O}$ resultado deste confronto/cooperação é a produção de leggi et ordini capazes de limitar a desmesura dos grandes e viabilizar um vivere libero et civile. Este espaço, porém, é impossível de ser estabilizado de forma definitiva, precisamente porque o movimento das partes conduz a uma permanente recombinação da relação de forças em jogo na cena pública.

O que Maquiavel teme é a vitória total de qualquer dos dois campos em confronto, porque isso destruiria o inteiro corpo político. É nesse sentido que deve ser entendida a crítica áspera que dirige tanto ao povo quanto aos nobres: devido ao "excessivo desejo" do primeiro de "ser livre" e ao "excessivo desejo" dos últimos de "comandar", arriscam dar origem à tirania. Com efeito, explica Maquiavel, quando grandes e povo "não se acordam na criação de uma lei em favor da liberdade, mas alguma das partes se lança a favorecer a uma delas, a tirania surge de imediato" (Discursos, I,40:28). Em História de Florença Maquiavel ilustra bem o risco implicado neste movimento: a derrota completa de uma das partes da cidade faz surgir uma nova divisão entre a parte vitoriosa que agora pretende representar o todo da cidade. Maquiavel parece, com isso, mostrar que o desejo do povo (e não apenas o desejo dos grandes) precisa igualmente ser contido dentro de limites bem definidos. Assim, o conflito é produtor de um vivere libero et civile somente enquanto permanece a tensão entre as forças em confronto; enquanto se produzem leis que não tenham em vista nem a vantagem de uma parte nem de outra, e sim a liberdade comum'; enquanto, enfim, não houver a submissão

5 É preciso ressalvar que a "liberdade comum" é, na verdade, a "liberdade do povo", como adiante esclareceremos, pois os grandes não desejam ser livres, e sim comandar. A propósito disso, Visentin chama a atenção, com razão, de que a liberdade do povo assume 
definitiva de uma parte a outra. Significa dizer: o espaço da liberdade política se encontra na resistência recíproca. Conclui-se dali que a liberdade jamais está dada, mas acontece sempre apenas enquanto. O desejo popular, que aparece como resistência ativa, é negativo (no sentido de definir-se por um "não" — de "não dominação") em sua oposição ao desejo positivo dos grandes (de dominação).

Em contraposição a este entendimento, Adverse (2007, p. 37), por exemplo, tem o entendimento de que o desejo popular "não pode ser compreendido apenas negativamente, porque ele envolve um princípio de ação". A oposição grandes/povo não pode ser compreendida nos termos de uma contrariedade formal de dois elementos excludentes e alternativos, ${ }^{6}$ argumenta o comentador: "caso se tratasse de uma contrariedade absoluta, a dinâmica da política se encerraria uma vez afirmado um dos desejos [...]. É porque não há contrariedade absoluta que os dois desejos podem, então, se afirmar e os conflitos manter rigorosa a vida política" (Adverse, 2007, p. 4I). Para sair da armadilha da compreensão da oposição de humores como contrariedade formal de elementos excludentes é preciso, pondera Adverse (Ibid., p. 37), "positivar o desejo do povo". Como se dá essa "positivação"? Para Adverse, na medida em que é suprida a demanda popular por participação no governo. Para corroborar este entendimento, Adverse (Ibid., p. 4I) recorda os exemplos romanos da criação dos tribunos e o direito de escolher os cônsules (no começo um e mais tarde os dois). Isto evidenciaria, segundo Adverse (Ibid.), que, para Maquiavel, a condição do povo de "ser guardião da liberdade implicava [...] o direito de exercer o poder, seja por via representativa, seja por via direta”. Dessa maneira, a recusa popular à dominação consistiria, de algum modo, em tomar parte no governo, em partilhar as magistraturas: "somente assim torna-se possível esclarecer como o desejo do povo pode refrear o dos grandes", conclui

uma configuração política, isto é, universal: "a liberdade é comum apesar dos grandes e graças ao povo e, neste sentido, negatividade e positividade do desejo se invertem nas leis" (comentário livre à versão preliminar do texto enviado por e-mail).

6 Muito embora a caracterização que oferecemos do confronto dos humores possa abrir espaço a uma leitura que o veja como uma "contrariedade formal de dois elementos excludentes", não é assim que o compreendemos. Com efeito, a relação não pode ser "A" versus "Não-A" simplesmente porque neste caso não existiria "relação", mas pura contraposição externa. Relação implica identidade na diferença e diferença na identidade. A pura equivocidade (ou contraposição exterior) é vazia de relação. Há relação entre grandes e povo, no modo como a compreendemos, na medida em que o movimento de uma parte provoca necessariamente a modificação da ação da outra parte. A cena pública é marcada pela contínua recombinação do jogo de forças. A lei, resultante desse riscontro de humores, não é a neutralização do conflito, mas é produção de meios de conservação de espaços de liberdade, ainda que sempre instáveis e provisórios, pois o espaço político é sempre modificado pelo surgimento de novas figuras e pelas relações que os atores políticos estabelecem entre si. 
Adverse (Ibid., p. 4I). Ressalte-se que o próprio Adverse (Ibid., pp. 44-45) alerta que compreender a "positivação" do desejo de não dominação do povo como desejo por participação nas instituições de governo não é sem riscos, dada a proximidade da pulsão popular em relação à pulsão antagônica fazendo com que a participação nas magistraturas acabe facilmente desandando em ambição de poder, de modo que poderíamos falar em uma boa e uma má positivação do desejo negativo do povo, pensa ele.

Para além das observações já feitas por Cardoso (2015, p. 232), ao alertar sobre as dificuldades destas consideraçôes relativas à 'positivação' do humor popular, somos do entendimento de que o modo como Adverse compreende as coisas torna algo difícil distinguir o desejo negativo do povo (não dominação) do desejo positivo dos grandes (dominação), pois o humor de ambas as partes se realizam pelas mesmas coisas (ou seja, pelo exercício das magistraturas). Significa: ambos parecem animados por desejos "positivos".

Como procuraremos mostrar mais adiante, entendemos que, devido ao caráter "negativo" do desejo popular, não cabe falar em "positivação" na forma de exercício de funções públicas, como defende Adverse. Tentaremos mostrar que a resistência à opressão dos grandes produz lei e instituições, mas o povo mesmo está sempre fora do exercício direto (ou mesmo pela representação') destas. Em outras palavras, ainda que a motivação do povo de querer liberdade esteja ligada à posição de subalternidade que ocupa na cidade, ele não se livra desta posição conquistando o domínio, mas sim pelas leggi et ordini capazes de limitar o domínio dos grandes. Desta maneira, muito embora o desejo popular seja negativo (na medida em que se expressa como resistência ao desejo de comandar dos grandes), não é uma "negatividade absoluta" ou "radical" porquanto nesta resistência exprime precisamente uma potência "vital", "ativa" que, todavia, não se reduz jamais às instituições que nascem dela. O povo é sempre exterior ao exercício do instituído, e é precisamente nisso que consiste toda vitalidade da ordem política, pois assegura um campo crítico que permanentemente "descristaliza" ou, "desossifica" a ordem instituída

7 O entendimento de Adverse é de que o compartilhamento das magistraturas poderia dar-se, inclusive, "pela via representativa": para Maquiavel, "ser guardião da liberdade implicava [...] o direito de exercer o poder, seja por via representativa, seja por via direta" (Adverse, 2007, p. 4I). O conceito de "representação" de que Adverse se vale aqui indica algo próximo ao entendimento moderno no sentido de alguém que "toma o lugar de" e que "age em seu nome". Este sentido não nos parece pertinente ao pensamento maquiaveliano. Não nos parece que Maquiavel tenha atribuído semelhante valor representativo ao exercício de funçóes públicas.

8 Devemos a Visentin esta caracterização. Ele, com razão, alerta de que, se o desejo do povo fosse "radicalmente" negativo, não teria como, obviamente, afirmá-lo como uma "potência ativa". 
mantendo vivo e contínuo o fluxo da mudança. ${ }^{9}$

Muito embora o ideal do vivere libero et civile implique na necessidade de o bem da cidade sempre prevalecer sobre o bem das partes em confronto, seria um equívoco interpretar isso segundo o modelo clássico aristotélico de um primado ontológico do todo sobre as partes. Antes, se as partes em conflito são capazes de ceder em suas aspiraçôes é porque veem nisso a melhor alternativa para a realização de seu humor próprio. Para assegurar o vivere libero et civile é preciso que a cidade não "pertença" a ninguém, nem aos grandes, nem ao povo. ${ }^{10}$ Deixar livre curso às disputas significaria deixar livre curso aos desejos de domínio e correr o risco de perder a liberdade pura e simplesmente.

Isso, porém, não implica em renunciar ao argumento maquiaveliano de que os tumultos são a principal causa da liberdade política. Maquiavel o estabelece em um duplo momento: primeiro, que os desejos (ou umori) representam as forças que estimulam os homens a agir; segundo, que a manutenção das tensões entre grandes e povo tem por efeito que nenhuma das partes será capaz de prevalecer sobre outra, o que implica na invenção de mecanismos institucionais de controle. Com isso queremos dizer que a realização do desejo popular por liberdade se efetiva não pelo exercício ("direto ou por representação") das magistraturas, e sim pela criação de mecanismos institucionais por meio dos quais se impede a possibilidade a qualquer das partes "a ocupar o lugar do poder", como ensina Lefort. Aqui nunca é demais insistir em que estes mecanismos institucionais não se impõem "de fora" às partes, pois são o resultado mesmo do confronto. A lei que regula o movimento das partes não

9 Adverse questiona de que "dificilmente poderíamos conciliar esta caracterização com aquela outra de guardião da liberdade. O guardião deve conservar a liberdade e assegurar a estabilidade das instituições. Portanto, o povo não é meramente uma potência negativa, muito menos o é seu desejo. Certamente, a manifestação desse desejo se dá negativamente como resistência à opressão, mas esta negatividade seria desprovida de efeito político se não coincidisse com a abertura para o governo das leis" (comentário livre à versão preliminar do texto enviado por e-mail). A questão que demandaria um aprofundamento teórico aqui seria a de caracterizar de que modo o povo, para Maquiavel, exerce a função de "guardião da liberdade", ponto que nos levaria, porém, a alongar em demasia as dimensões deste trabalho. Em todo caso, somos do entendimento de que, se o povo, como guardião, "deve conservar a liberdade e assegurar a estabilidade das instituiçôes", ele cumpre esta tarefa na resistência à pretensão dos grandes de apropriar-se das instituições em benefício próprio, o que exprime uma potência ativa que faz nascer leggi et ordini, mas não por meio do exercício (direto ou não) das magistraturas, como o entende Adverse. Já em relação à afirmação de que "povo não é meramente uma potência negativa", pensamos haver esclarecido a questão quando afirmamos que não se trata de uma negatividade "radical" ou "absoluta", e sim "relativa".

Io Como é sabido, é Lefort quem nos ensinou de modo sobremodo enfático de que o "poder é um lugar vazio": "ninguém tem autoridade para decidir assuntos que dizem respeito a todos, isto é, para ocupar o lugar do poder” (Lefort, I999, p. I70). 
é um cerceamento externo, como se ela surgisse contra os humores. A lei surge não contra os humores e sim dos humores.

Entendemos que interpretar a relação grandes/povo desta maneira não a faz recair na oposição simétrica de duas forças que se equilibrariam pela mútua vigilância dos opositores, tal como, com acerto, Cardoso critica em Skinner. ${ }^{\text {II }}$ A assimetria da relação grandes/povo - compreendendo-se o exercício da negatividade do desejo popular (de não dominação) pela resistência ativa ao desejo positivo dos grandes à dominação — se evidencia pela localização espacial dos atores. Como o expressa com clareza Frosini (20IO, p. I04): "a colocação espacial do povo determina sua luta como a única que pode ter real interesse na liberdade enquanto existência de um espaço público". Com efeito, não há como os grandes terem interesse na liberdade, porque ocupam a posição que se determina como "desejo de dominar" sendo, por isso, inconciliável, por definição, com o desejo popular de liberdade. Há, pois, uma assimetria de princípio nesta relação. Contudo, muito embora o desejo do povo seja o de "não ser dominado", ele é, sustenta Frosini (Ibid.), "ontologicamente idêntico ao das outras partes, grandes e príncipes". A afirmação paradoxal do comentador se torna mais clara se considerarmos que Maquiavel é sem ambiguidades quando afirma que o povo deseja "não ser dominado" (Discursos I,4-5), mas que é o mesmo povo que quer "com a nobreza dividir os cargos e o patrimônio como a coisa mais estimada pelos homens" (Discursos 1,37:6). Esta mudança de perspectiva na ordem do desejo se deve a que, segundo Maquiavel, "toda vez que é tolhido aos homens o combater por necessidade, combatem por

II Na verdade, Cardoso entende que a interpretação oferecida por nós acerca da relação grandes/povo seria igualmente "skinneriana", ainda que com modulações que a distinguiram, em alguns pontos, desta. Ao comentar o modo como elaboramos, em artigo publicado em 2009, a relação grandes/povo, Cardoso (2015, p. 223) escreve: "Aqui o poder se manifesta sempre como força; requer apenas ser limitado por seu opositor, inerentemente inapto para o governo. E o desejo de comando e a opressão (de alguns poucos) revela-se, afinal, mais benéfico à cidade que a aspiração (do grande número) pela 'liberdade'. Não haveria mais propriamente um poder da Lei, apenas a força da dominação dos grandes (desejável esta, enfatizamos, desde que limitada pela resistência do desejo popular, tendencialmente anárquico). Na verdade, o princípio da ordem está, aqui, do lado dos grandes; são eles os verdadeiros guardiōes da Liberdade, da produção e conservação da vida civil" (grifos nossos). Na análise de Cardoso, teríamos invertido a proposição maquiaveliana da guarda da liberdade, colocando-a nas mãos dos grandes em vez das do povo. Por certo não terá sido por acaso que Cardoso interpretou desse modo nossas formulações acerca da relação entre grandes e povo. O texto muito possivelmente contribuiu para que este equívoco se produzisse. Queremos destacar, porém, que parece haver nesta compreensão um estreitamento da interpretação ao afirmar que não haveria mais propriamente um poder da Lei, apenas a força da dominação dos grandes. Contrariamente a isso, temos insistido de que, para Maquiavel, a regulação social se dá pelas leggi et ordini. Diferente da conclusão de Cardoso, portanto, reafirmamos que o "o poder é da Lei” e não "da força da dominação dos grandes”. 
ambição" (Discursos I,37:3). O que Maquiavel parece nos levar a entender é de que em sua "estrutura antropológica" os homens têm os mesmos desejos e paixóes. Maquiavel reafirma, por sinal, esta tese nas suas diferentes obras. ${ }^{\mathrm{I}}$ Com isso deixa patente que não existe uma relação essencial entre povo e liberdade ${ }^{\mathrm{r} 3}$, como se o único desejo que anima o povo fosse o de viver livre, e jamais o de exercer a dominação sobre a parte adversária.

Apesar de os humores serem, como diz Frosini, "ontologicamente idênticos", não podem ser completamente equiparados, porque se confrontam em posiçôes diferentes do espaço político das relações de poder: de "comandar" (os grandes) e de "não ser comandado" (o povo). Assim, embora o povo não esteja essencialmente (ou "ontologicamente") ligado à liberdade, como afirma Frosini, não é por acaso que o desejo de liberdade está ligado à posição ocupada por ele, e jamais àquela ocupada pelos grandes. Em outras palavras, a ligação do povo com a liberdade não é casual, como se o povo estivesse acidentalmente ligado à liberdade, e que isso poderia igualmente acontecer, eventualmente, também com os grandes: estes, pela posição de dominação que exercem, estão animados pelo desejo de oprimir e, consequentemente, simplesmente não têm como ligar sua existência política à liberdade. $\mathrm{O}$ desejo dos grandes é sempre parcial por estar ligado a âmbitos particulares da vida política (como cargos, bens e honras); por ser desejo por bens determinados, pressupõe a exclusão da outra parte (o povo). O desejo do povo, pelo contrário, por estar na posição de quem sofre a dominação, necessariamente resiste à opressão exercida pelos grandes, ou seja, está movido pelo desejo de liberdade. Assim, o desejo do povo, mesmo sendo desejo de uma parte, é universal, pois implica, para sua realização, na inclusão de todas as partes - grandes e povo. Significa dizer: a liberdade desejada pelo povo, muito embora seja o desejo de uma parte, não é desejo de liberdade para o povo, mas liberdade do conjunto da coletividade política. Com efeito, unicamente na medida em que a vida política enquanto tal for livre será possível ao povo usufruir da liberdade à qual aspira. Dessa

I2 Veja-se, a propósito, o que Maquiavel escreve no texto "Do modo de tratar os povos do Vale do Chiana rebelados" (1986, p. 93): "o mundo sempre foi, de certa forma, habitado por homens que sempre tiveram as mesmas paixóes; e sempre houve quem serve e quem comanda, e quem serve de má vontade e quem serve de boa vontade, e quem se rebela e se rende". Igualmente pode ser conferida a passagem que consta em Discursos III, 43:3: "Isso ocorre porque, tendo sido feitas pelos homens, que têm e sempre tiveram as mesmas paixões, tais coisas só poderão, necessariamente, produzir os mesmos efeitos”.

I3 Por vezes o excelente artigo de Cardoso nos dá a impressão de que para ele o povo está "essencialmente" ligado à liberdade, de modo que, quando o povo passa a buscar os mesmos bens que os grandes, ele entende que deixa de ser "povo"; ou seja, de que quando age como "seita" ou "facção" não seria mais povo. Comentaremos mais adiante esta interpretação. 
maneira, pode-se dizer que o povo, ao reivindicar a própria liberdade, cria a possibilidade do gozo comum desta.

Nesse ponto o artigo de Sérgio Cardoso, em excelente exegese das formulações de Lefort relativas à natureza do desejo negativo do povo, é útil para compreender como se dá a relação das forças em confronto. Para Cardoso, é a pulsão popular para a liberdade que produz a ordem política, a ordem da lei ou da liberdade. Ela irrompe para além do jogo sócio-econômico das oposiçóes de interesses que rivaliza todos os homens, que lhes infunde a pulsão de defender-se e de se sobrepor aos demais. Assim, explica Cardoso (2015, p. 235), "o grande número dos 'sem poder' [...] se faz 'povo', classe política, ao se manifestar como portador do 'humor popular', ao afrontar o desejo de opressão dos "grandes””. Ocorre, porém, que este enfrentamento pode não ter lugar, e isso por diferentes razões, lembra o comentador: devido à incapacidade do "grande número" de se juntar na oposição à opressão dos grandes; por causa da dispersão motivada pelas lutas facciosas dos grandes; ou, ainda, pela corrupção da pulsão negativa do povo em desejo de poder. Quando se configura esta situação, escreve Cardoso (Ibid., p. 236), "desaparece o 'povo', a atuação do desejo popular. A cena política 'falha' e as forças se homogeneízam nas lutas por interesse e nos embates de facções por poder; não há mais povo como categoria política".

"Povo", deve, pois, ser compreendido sob o registro político, isto é, o que quer lei, o que quer o regime político da liberdade. Neste sentido, é legítimo falar, argumenta Cardoso, "fazer-se povo", ser "portador do humor popular", independente da posição sócio-econômica, pois o que define a condição de "povo" é ser possuidor de determinado "humor" (ou "desejo"), e não a de ocupar certa posição socioeconômica ou exercer determinada função política. Valendo-se das análises de Lefort (1972), Cardoso (2015, p. 226) ressalva: "É verdade que a pulsão dos grandes, dirigida aos bens e riqueza, pode indicar alguma positividade que se veja alheia à encenação política, mas a pulsão popular, dada sua natureza negativa, não pode ser concebida senão na, e pela, atividade instada por sua repulsa à opressão". Em suma, povo assim compreendido — isto é, sob um registro político - estaria destituído de qualquer substancialidade, pois, tomado como humor/desejo, é captado unicamente como atividade (isto é, como pulsão ou desejo).

Compartilhamos com Cardoso da ideia de que "povo" só é compreendido adequadamente em Maquiavel se o for como categoria política. No entanto, apesar de concordar com a tese central, é difícil dizer o mesmo em relação a todas as consequências que ele deriva dela. Com efeito, dada a abstratidade da categoria povo sob o "registro político", ao menos do modo como Cardoso a compreende, não faz perder de vista a história, a "verdade efetiva"? Para Cardoso, vimos, a "corrupção da pulsão negativa do povo em desejo de poder" o destitui como 
"povo", "desaparece o povo", insiste ele. Ora, se um povo corrompido não é mais "povo", o que é ele? Não seria melhor dizer que, quando a "pulsão negativa do povo" se converte em "desejo de poder", ele permanece "povo" - em vez de dizer que se descaracteriza como "povo" - , porém modifica sua estrutura ${ }^{\mathrm{I}}$ ?

A conclusão de Cardoso - de que povo convertido em facção não é mais povo - encontra na análise de Stefano Visentin um contraponto sugestivo. Visentin concorda em que "povo", para Maquiavel, não existe em sentido abstrato, mas disso não decorre segundo o comentador, ao contrário do que defende Cardoso, que "povo" não tenha uma identidade e uma substância: "Povo possui uma identidade e uma substância na medida em que se apresenta — tornando-se visível — na cena política: em estrita analogia com o príncipe novo, também o povo é o que parece ser - e age, na medida em que aparece sob uma figura determinada" (Visentin, 20I5, p. 369). Tornar-se visível significa ter a possibilidade de ocupar um espaço político, produzindo assim efeitos que podem influenciar outros atores políticos - e, por sua vez, a possibilidade de ser influenciado e modificado por eles. Dessa maneira, na medida em que o povo aparece à cena política, ele é́; ou seja, ele é na medida em que se torna visível no espaço público e é aquilo que ele parece ao aparecer. No entanto, concordamos com Cardoso quando (em comentário livre à versão preliminar deste trabalho) pondera que "o 'povo', visto que age, aparece (e faz história); tem realidade (a palavra 'substância' seria aqui muito inadequada) política — aliás, refere-se a ele a realidade da ordem política (por oposição a uma ordem despótica, a uma não-ordem anárquica, a ordens apenas aparentemente políticas)" . ${ }^{\text {Is }}$ Ou seja, o reconhecimento de que o povo emerge a cena pública sob "rostos" diversos, segundo as conjunturas e circunstâncias históricas concretas, implica que tenha "realidade" ("política", como defendem Visentin e Cardoso), mas esta realidade não pode ser confundida com "substância”, apesar de cada modo de aparecer conferir ao povo uma identidade singular, uma "realidade" cada vez própria. Assim, alinhamo-nos à ideia de Cardoso, de que o aparecer do

I4 Em comentário livre à versão preliminar deste trabalho, Cardoso reafirma seu entendimento de que "o conceito de 'povo' só pode ser tomado em sentido próprio enquanto designa (ou aspira por, ou deseja) o 'universal' (um 'todos', que põe o espaço efetivamente político). E penso que esse humor 'popular' (que recusa a opressão da particularidade, dos desejos particulares, essencialmente ligado a 'bens', econômicos), é sempre portado por, está sempre investido em, uma parte da sociedade ('pars totalis', num certo sentido) e que esta parte, que se opõe à opressão dos grandes, pode também não mais agir politicamente, atuando como facção, ou seja, não em função da produção de leis, de universais políticos, mas em função de interesses de parte."

I5 Visentin, comentando a versão preliminar deste trabalho, manifestou sua concordância com a posição de Cardoso, reconhecendo que o uso que ele havia feito do termo "substância" teria sido impreciso neste contexto. 
povo à cena pública lhe confere uma realidade política, do que, no entanto, não se depreende que possua uma "substancialidade" — nem econômica, nem sociológica.

Este surgimento do povo, isto é, o seu tornar-se visivel, pode acontecer de diferentes maneiras, dependendo das circunstâncias históricas e políticas. Quais são as modalidades de aparecer do povo? Stefano Visentin (2015) distingue quatro figuras ("faces" ou "rostos") que dão visibilidade ao povo: povo como plebe, povo como multidão, povo como príncipe e povo como facção. ${ }^{16}$ Dadas as limitações de espaço deste trabalho, não temos como examinar estas diferentes "faces" sugeridas por Visentin. Permitimo-nos, porém, ressaltar que, tomandose o povo como uma figura multiforme que assume uma identidade de acordo com o papel que exerce em seu aparecimento à cena pública, a ação facciosa do povo continua sendo o exercício da ação política de "povo".

\section{Povo como potência instituinte viva}

Mostramos até aqui que a concepção de povo em Maquiavel pode ser apreendida corretamente unicamente se o for sob o registro político, destituído, portanto, de "matéria" empírica, seja esta sociológica ou econômica. Descrevemos também a dinâmica própria ao conflito dos humores no pensamento de Maquiavel como de riscontrolencontro (confronto e cooperação). Trata-se agora de mostrar como, para Maquiavel, este ator 'povo' se constitui em "potência instituinte" da ordem política como sua permanente força viva.

Vimos que Maquiavel insiste em que a resistência do povo ao desejo de dominação dos grandes não acontece sem tumultos, de modo que "considerar tão somente o barulho e a gritaria (a'romori e alle grida) que nascem dos tumultos" (Discursos 1,4:5) é não compreender os bons efeitos que os conflitos produzem. O conflito é, na verdade, causa de efeitos institucionais virtuosos necessários para defender e preservar a liberdade do povo. Foi o caso, por exemplo, explica Maquiavel, da criação dos Tribunos na Roma republicana, instituição criada "depois de muitas confusões, tumultos e perigos de perturbações surgidos entre a plebe e a nobreza" (Discursos I,3:9). Aparece aqui a necessidade da ligação entre conflito e lei, entre os momentos factual/político e normativo/jurídico: a criação da instituição do tribunato romano (momento normativo/jurídico) é resultado de um processo histórico de luta da plebe (momento político/factual).

I6 Cardoso (20I5) dá a entender que Maquiavel só reconhece um único modo de aparecimento de povo à cena pública. O estudo levado a efeito por Visentin mostra que é possível identificar diferentes modos de aparecer do povo, segundo as circunstâncias e conjeturas históricas determinadas, os quais não podem sem mais ser reduzidos a uma "forma" única. 
Esta relação entre os dois momentos - factual/político e normativo/ jurídico - pode ser captada de modo mais claro na distinção feita por Maquiavel entre dois modelos constitucionais, o espartano e o romano: no primeiro, as leis são dadas de uma só vez por um sábio legislador; no segundo, surgem no curso da história. Nas palavras de Maquiavel: "algumas [cidades] receberam leis, em seu princípio ou depois de não muito tempo, de um só homem e de uma só vez - como as leis que foram ditadas por Licurgo aos espartanos - e outras as receberam ao acaso e em várias vezes, segundo os acontecimentos, como ocorreu com Roma" (Discursos I,2:3). Nas categorias que estamos utilizando, no modelo romano, preferido por Maquiavel, não temos uma forma constitucional definitivamente dada — como foi o caso do modelo espartano —, mas em contínua e permanente construção, pois a lei permanece aberta à história, ao conflito. Com isso, o povo, como potência instituinte, permanece força viva de invenção permanente da lei, coexistindo com o aparato jurídico-político estabelecido (o momento instituído). ${ }^{17}$ É possível atribuir aos conflitos o papel de "inventar" novos ordenamentos sem ameaçar a existência da cidade em virtude de seu caráter "instituinte" e não "constituinte"; ou seja, são manifestações de uma "potência" (força, capacidade) e não de um "poder" juridicamente reconhecido.

I7 Adverse questiona, com razão, nossa afirmação de que o povo, como força viva de invenção permanente da Lei, coexiste com o aparato jurídico-político estabelecido. Segundo ele, com isso: (a) estaríamos retomando a ideia de positivação; (b) precisaríamos recorrer a "uma teoria jurídica do poder", ideia que seria estranha ao pensamento maquiaveliano; e, finalmente, (c) acabaríamos pressupondo uma "vontade geral" (comentário livre à versão preliminar deste texto enviado por e-mail). Consideramos pertinentes os questionamentos, e pretendemos em outro momento dedicar-nos a eles para aprofundar melhor a questão. Por ora limitamo-nos a reforçar que a natureza política do confronto entre grandes e povo faz com que o conflito tenha por destinação sua conversão em algo "institucional” (leggi et ordini) e não uma confrontação aniquiladora de uma parte pela outra (seria guerra civil). Na medida em que a liberdade é o desejo próprio da parte popular, e pelo fato de as leggi et ordini resultantes do conflito terem por "matéria" a salvaguarda da liberdade, podemos dizer que o humor popular "se positiva" nos ordenamentos institucionais, ele ser faz "presente" neles. Assim, pensamos que se pode chamar esse processo de "positivação do desejo popular", como quer Adverse, apenas no sentido de criação de estruturas legais (leis e instituições), mas não no sentido de exercício, "direto ou por representação", de funções públicas. Pressuporia isso uma "vontade geral"? Não nos parece, pois as leggi et ordini brotam do conflito e, por conseguinte, não têm como ser uma inteira e única expressão do desejo popular (e, sequer, de uma "vontade geral" como comunidade política, como "corpo político", nas palavras de Rousseau, sem diferenciação interna de "partidos"). Visentin, a propósito da mesma questão, nos questiona: "Mas é possível distinguir tão claramente os dois planos [factual/político e jurídico/normativo]? Ou se trata de uma distinção 'artificial' que não pertence ao contexto teórico de Maquiavel?” Por certo a distinção destes planos resulta da interpretação do processo descrito por Maquiavel nos Discursos e, neste sentido, não se trata de categorias refletidas pelo próprio florentino. Apesar disso, nos parece possível depreender da análise maquiaveliana uma diferenciação entre os planos factual e jurídico ou entre os planos político e normativo. 
Aparecem aqui os elementos centrais do nosso argumento. Para Maquiavel: (a) as leggi et ordini são o resultado da dinâmica de confronto/cooperação entre povo e grandes; (b) o conflito entre grandes e povo não é simples confrontação de interesses, mas oposição de projetos políticos (dominação versus não dominação); (c) o confronto tem em vista um resultado institucional, a criação de mecanismos legais de controle da desmesura, particularmente do desejo de opressão dos grandes; (d) as leggi et ordini emergem do (e não contra o) tumulto e, por isso, não se impõem externamente às partes em confronto; (e) pelo fato de as leggi et ordini resultantes do conflito terem por "matéria" a salvaguarda da liberdade, podemos dizer que, de certo modo, o humor popular "se positiva" nos ordenamentos institucionais; (f) o que impede às leggi et ordini "se cristalizarem" sob o aparato jurídico-político é a condição de exterioridade do povo como potência instituinte viva que, em virtude de o conflito ser constitutivo da cidade, conserva a provisoriedade de todo o instituído; (g) a forma constitucional jamais está definitivamente instituída, um aparato jurídico-político definitivo com autoridade soberana, uma vez que a luta política, que se dá na esfera factual e pré-legal, conserva sua condição de potência instituidora do normativo/jurídico. Na sequência detalharemos um pouco mais e melhor estes pontos.

A opção de Maquiavel pela forma de produção constitucional romana é paradoxal, considerando que "Esparta observou [as leis] por mais de oitocentos anos sem as corromper ou sem nenhum tumulto perigoso" (Discursos I,2:5), ao passo que Roma viveu sob uma república menos da metade deste tempo. A vantagem do modelo espartano, que conta com uma constituição perfeita desde as origens, é a estabilidade e duração. Maquiavel parece sacrificar essas duas determinações essenciais do modelo espartano, estabilidade e duração, em favor de uma determinação ainda mais essencial: a liberdade, sobretudo a capacidade de ampliar a liberdade externa e interna, sempre que a necessidade induzir a isso. A estabilidade do modelo espartano pode muito bem converter-se num impedimento para a expansão da liberdade, com consequente anulação do conflito a favor de uma concórdia forçada.

A afirmação da liberdade como princípio essencial do modelo republicano concebido por Maquiavel, longe de excluir a igualdade, a pressupố ${ }^{\mathrm{I} 8}$ : "[...]

I8 Liberdade e igualdade, para Maquiavel, antes do que "valores", são os "descritores" essenciais de seu republicanismo. Ambas ao mesmo tempo em que são como que "efeitos" gerados pelas instituiçóes republicanas, precisam existir previamente para que uma ordem republicana se instaure. Mostra-se aqui o caráter histórico da concepção política maquiaveliana: tudo está em contínuo processo de transformação, de modo que não se trata mais de falar de um "antes" e um "depois" em relação a liberdade e igualdade. 
que se constitua, portanto, uma república onde existe ou se criou uma grande igualdade e, ao contrário, que se ordene um principado onde existe grande desigualdade, caso contrário se fará algo sem equilíbrio e pouco durável" (Discursos $\mathrm{I}, 55: 35$ ). Esta assimilação do princípio da igualdade ao fundamento da ordem republicana, como sua prévia condição de possibilidade, estabelece uma intrínseca correspondência com o princípio e objetivo da liberdade. ${ }^{19}$ Enquanto a liberdade é elemento constitutivo da república, mas também conteúdo e objetivo do desenvolvimento republicano, a igualdade é sua condição de possibilidade: sem ela, não é possível fundar uma república. Mais radicalmente ainda, Maquiavel afirma que a aristocracia feudal não somente impede o nascimento de um regime republicano, mas impossibilita qualquer outra forma de organização estatal que não seja tyrannica: ao contrário da vita libera republicana, aquela representa a corrupção, a destruição das ordini e da vita civile. Numa palavra: desigualdade identifica-se com a ausência de vivere político et civile, pura e simplesmente. ${ }^{20}$

Assim, uma vez que a primeira constituição romana não foi imposta de fora por um sábio legislador, a história ganha toda sua importância, porque sua legislação foi elaborada "no curso dos acontecimentos". Trata-se, portanto, de compreender como uma origem tão modesta, tão afastada da perfeição, foi possível sem se afastar do diritto cammino (Discursos 1,2:6). Vamos situar a questão, ainda que apenas indicativamente.

No capítulo ir do Livro I dos Discursos Maquiavel, servindo-se de Políbio, descreve o ciclo sucessivo de constituições simples, da degradação inevitável das constituições boas em más. Para Maquiavel, a três formas sadias — principado, optimates e popular — são boas não porque são frutos de uma escolha, e sim porque nascem de uma necessidade: fazer frente a uma urgência, respectivamente à tirannide, ao stato di pochi e à licenza. Enquanto a urgência está vivamente presente, se pospóem "todas as comodidades à utilidade comum"

I9 Não se trata, evidentemente, de dois conceitos diversos de liberdade, e sequer, talvez, de sua "transformação" no tempo. Trata-se, antes de compreender que a "mesma" liberdade que define a condição republicana é também aquela se produz no curso do tempo pela luta política e, por isso, é intrinsecamente marcada por sua precariedade e instabilidade, jamais como algo dado em definitivo.

20 Evidentemente, trata-se aqui da crítica maquiaveliana à desigualdade produzida pela presença da aristocracia feudal e não daquela criada pela nobreza della roba, da qual Maquiavel fala em História de Florença. Quer dizer, e como mostra com muita propriedade Gabriel Pancera (20I0, pp. 86-87), a desigualdade que inviabiliza a vida política livre não é a que se funda sobre a diferença de classes oriunda da riqueza. A igualdade que Maquiavel reclama como fundamento da república é a igualdade política compreendida como igualdade de comando e ausência de precedência/privilégio. É, precisamente, essa igualdade que fica comprometida pela existência de uma aristocracia feudal. 
(Discursos 1,2:20). Contudo, na medida em que as gerações se sucedem, esta urgência empalidece e as leis e instituições que nascem dela perdem seu suporte (isto é, a virtuosa necessidade) deixando lugar à ambição e, desta maneira, corrompem-se e abrem espaço à nova urgência; e assim ad infinitum.

A questão que Maquiavel levanta é, pois, a seguinte: o que conservaria a necessidade, o que seria capaz de manter permanentemente presente o risco da corrupção, alimentaria o temor da corrupção, evitaria o esquecimento da origem? Para Maquiavel, o que torna isso possível é o conflito, questão à qual nos introduz ao final do capítulo II (e continuará até o capítulo vI). Com efeito, o conflito não somente contém essa força constritiva própria à necessidade (porque deixa patentes os interesses contraditórios e inconciliáveis de grandes e povo, assim como a urgência de dar solução satisfatória aos mesmos), mas impõe uma decisão na discórdia (quer dizer, sem que esta seja neutralizada). O conflito, segundo Maquiavel, fez com que a nobreza, "para não perder tudo, se obrigasse a conceder ao povo a sua parte” (Discursos I,2:34). Significa dizer que a nobreza foi obrigada a conceder ao povo o lugar que lhe cabia no governo da cidade, reconhecê-lo como força política, mas significa igualmente reconhecer a natureza constitutiva da cidade: todas estão marcadas pela conflito. A autoridade não é desequilibrada a favor de uma parte, mas permanece dividida - isto é, compartilhada - entre as forças que a compóe e foi sobre esta base que Roma, "permanecendo mista, constituiu-se numa república perfeita" (Discursos I,2:36). ${ }^{21}$ A república romana foi una no sentido de ser composta de partes (cônsules, senado e povo) as quais, "permanecendo tais" (isto é, conservando a distinção, permanecendo partes) governaram (os nobres por meio dos cônsules e o senado; o povo pelos tribunos) cada qual com suas funções específicas.

$\mathrm{Na}$ descrição do governo misto, Maquiavel afirma que a república conseguiu se aproximar da perfeição do governo misto no curso da história e não seguindo as ordini de um sábio legislador, como Licurgo em Esparta. $\mathrm{Na}$ base do modelo romano está, pois, a necessidade nascida do conflito, e não uma escolha entre outras possíveis. A cidade é um espaço de conflito, conflito que a divide desde a origem, de sorte que sua unidade se funda sobre um dualismo: os humores de grandes e povo.

2I Cabe destacar que o significado de "república mista" em Maquiavel é bem diferente daquele de Políbio. Enquanto para este a composição das partes é racionalmente pensada, para Maquiavel a constituição é necessariamente mista pelo fato de nas cidades as forças se confrontarem e o esforço de contrabalançamento não se esgotar jamais, porque jamais se esgota o impulso dos humores. Por isso, somente se confrontando as forças podem encontrar pontos de equilíbrio mais ou menos duradouros, mas nunca capazes de colocar fim às lutas. Desta maneira, "misto" em Roma não é sinônimo de "fusão", mas antes de "junção", que se articula sempre em conformidade com as circunstâncias e conjunturas concretas. 
Este modo de pensar institui o povo, de certo modo, em "sujeito legislativo", mas pensamos que de forma negativa (pela resistência, pela oposição - pelo "barulho e gritaria" - a'romori e alle grida), e não de forma positiva. Cardoso (2015, p. 244) oferece uma interpretação que nos parece ir a outra direção. Com efeito, mesmo reafirmando que o desejo popular é "originalmente indeterminado e puramente negativo", o comentador ressalta que ele não deixa por isso de ser "politicamente produtivo e de ocupar o lugar de sujeito da produção das leis".

A maneira com a qual Cardoso apresenta a produção legislativa dá a impressão de estar mais perto da formulação rousseuniana de "vontade geral" do que da concepção maquiaveliana de lei. Com efeito, para Rousseau lei é expressão da "vontade geral" exercida pelo "corpo político" íntegro, isto é, sem a interferência de "partidos" ou "seitas". O povo rousseaniano se orienta sempre em suas decisóes pelo bem comum, sua decisão é sempre expressão da vontade geral. Quando a "vontade particular", ou mesmo a "vontade de todos", prevalece já não temos mais uma manifestação soberana do "povo", mas de facção. Cardoso, na passagem destacada, parece querer nos fazer entender de que, para Maquiavel, o povo é uma espécie de "legislador" em um sentido praticamente coincidente com o rousseauniano. Significa dizer: que para Maquiavel determinada manifestação política só seria expressão do "povo" na medida em que expressa a universalidade, à semelhança da "vontade geral" de Rousseau. Com efeito, quando afirma que "é possível ver nele [no povo] o próprio 'autor' das leis, o sujeito mesmo da invenção histórica de direitos" (Cardoso, p. 245), parece querer indicar que o povo desenvolve ele próprio diretamente a atividade legislativa à semelhança do "corpo político" rousseauniano indiviso. Isso fica mais claro ainda quando afirma que "o humor negativo do 'povo' não é mais [...] princípio de independência e desordem (rebeldia anárquica a toda ordem e governo)" (Cardoso, p. 245). Com esta ideia Cardoso parece excluir a possibilidade de a produção legislativa poder ser um processo decorrente de uma resistência popular à opressão dos grandes; quer dizer, parece não levar em conta que para Maquiavel povo é sempre parte, ainda que seu desejo seja um universal, que rivaliza com outra parte (os grandes), cujo desejo é sempre parcial.

Como entender, pois, o povo como "autor" da lei? Temos insistido de que o povo cumpre essa função na medida em que resiste à opressão dos grandes. Não se trata, portanto, de um autor à moda rousseauniana, por exemplo. Assim, rigorosamente falando, talvez não seja sequer apropriado dizer que exista um "autor" da lei em Maquiavel, seja porque ela brota de uma confrontação de interesses divergentes, seja porque a lei para florentino está sempre por se fazer, está permanentemente exposta à transformação. Assim, aquilo que a modernidade designará "poder constituído", em Maquiavel ainda não tem a dimensão do 
"constituído" como se estivesse definitivamente estabelecido. Em lugar de um "constituído" seria, talvez, mais apropriado falar de "em processo de instituição", no sentido de jamais concluso, pronto ou acabado.

Para compreender de que modo, segundo Maquiavel, permeiam entre si estes dois momentos (instituinte e instituido), precisamos ter em conta a necessidade, manifestada por Maquiavel, da existência de estruturas capazes de satisfazer os humores: "nada há que faça mais estável e firme uma república do que ordenála de tal modo que a alteração daqueles humores que a agitam encontre via de desafogo (una via da sfogarsi) ordenada pelas leis" (Discursos I,7:6). Em linguagem mais próxima à nossa mentalidade isso significa manter a conexão entre o aparato jurídico-político formal e o espírito que originariamente guiou sua fundação. É a partir deste contexto que a questão do "poder constituinte" — que os contratualistas modernos remetem ao povo - precisa ser pensada.

A intenção de Maquiavel é derrubar a afirmação tradicional da superioridade dos regimes mistos baseados na harmonia e concórdia. Embora Roma nunca tivesse tido um Licurgo, "constituiu-se em uma república perfeita" graças à "desunião entre plebe e senado" (Discursos I,2:36). Esta tese é defendida por Maquiavel contra uma longa tradição que remonta a Aristóteles e que era mantida viva em seu tempo pelo "humanismo cívico" florentino. Em oposição ao princípio tradicional do equilíbrio dos poderes e do equilíbrio pacífico das forças sociais, Maquiavel propõe a mistura como resultado do confronto (scontro) — uma unidade conflituosa entre duas, em vez de três, forças sócio-políticas: povo e grandes. $\mathrm{Na}$ análise de Maquiavel acerca da história romana levada a efeito nos Discursos, o momento instituinte romano nunca correspondeu ao exercício de uma vontade homogênea das forças políticas divergentes em sua convergência a um projeto constitucional plenamente representativo. Por isso, como dissemos mais acima, em Maquiavel não se trata ainda de um "poder constituído" no sentido de algo acabado, pronto, e que se exerce soberanamente sobre o conjunto da coletividade política. Significa dizer, na análise do modelo romano Maquiavel deixa claro que não apenas o desejo dos grandes permanece irredutivelmente parte, mas igualmente o humor popular continua parte. Diferente do que pensava a tradição, Maquiavel não compreende o regime misto como convergência de forças sociais distintas em torno de um projeto suficientemente consensual para representar a vontade comum de todos. O modelo defendido por Maquiavel a partir da leitura feita por ele da Roma republicana é de um regime misto que se constitui no curso da história em base à oposição de grandes e povo. Ambos permanecem "partes", inclusive o povo.

Povo, em Maquiavel, em nenhum momento de sua obra, é concebido como "totalidade"; ele é sempre "parte", muito embora il universale (termo do qual seguidamente Maquiavel se utiliza para referir-se a "povo") seja movido por 
um humor (desejo de liberdade) universal, por oposição ao humor dos grandes (desejo de poder) necessariamente particular, pois supõe, para sua efetivação, a submissão da outra parte.

Como é possível imaginar uma lei viva capaz de incorporar o poder do momento instituinte, sem neutralizá-lo ou dissipá-lo? Para os teóricos modernos isso é impossível, pois para estes o poder constituinte aparece como uma dinâmica plural e polêmica que, em algum momento, converge para uma vontade única e homogênea a qual, representando a totalidade, institui a soberania estatal, de ora em diante fonte única de toda autoridade. A resposta de Maquiavel é, neste sentido, inovadora ao propor a coexistência dos dois momentos, factual/político e jurídico/normativo graças à manutenção da raiz conflituosa que caracteriza, por definição, o momento instituinte vivo.

O conflito dos humores pertence ao momento factual e pré-legal. Como os humores são constitutivos da vida política (e não, como se poderia supor, um momento empírico da luta entre grandes e povo), seria inútil pretender eliminálos. No entanto, seria também absurdo pensar que esses humores, próprios ao momento instituinte, não serão transformados em e através da dimensão jurídica. É por essa razão que a concepção de direito em Maquiavel se torna inconciliável com a função "neutralizante" que lhe é atribuída pelo direito positivo moderno. Com efeito, em Maquiavel o direito não é criado pelo soberano — seja ele um monarca ou uma assembleia —, mas é o resultado sempre instável, precário e provisório de uma luta entre forças políticas opostas — grandes e povo — de modo que permanece uma continuidade impossível de ser eliminada entre política (o factual) e direito (o jurídico). Este modo de pensar as coisas implica em duas questôes intrinsecamente relacionadas.

Em primeiro lugar, que o conflito tem em vista a produção de ordenamentos legais (leggi et ordini), isto é, uma forma de instituição permanente; ${ }^{22}$ ou seja, a luta é política, ela objetiva a criação de mecanismos institucionais capazes de dar permanência, certa estabilidade, àquilo que motivou a luta. Serão estes mecanismos, que Maquiavel denomina leggi et ordini, que manterão sob controle a desmesura, especialmente a dos grandes, e darão origem a um vivere

22 Acerca desta questão Miguel Vatter critica a abordagem de Antonio Negri. Segundo Vatter, Negri, a fim de resistir à absorção do componente constituinte dentro do poder constituído, cai na falácia oposta. Invertendo a relação, Negri definiria poder constituinte como uma força absoluta privada de qualquer relação com a forma jurídica instituída. "A tentativa de Negri para separar poder constituinte do poder constituído vai longe demais e não consegue estabelecer uma relação interna entre poder constituinte e poder constituído. A absolutização do poder constituinte de Negri tende a absolvê-lo de qualquer relação com o poder constituído [...]. Em consequência, para Negri a existência de uma 'relação interna' entre os dois termos implica necessariamente que um deles tem de ser “internalizado' pelo outro” (Vatter, 2002, p. 2I2). 
politico et civile. ${ }^{23}$ Em suma, a destinação dos humores conflituais que agitam a vida das coletividades (o momento factual/político) é converter-se em lei.

Em segundo lugar, além de a destinação dos humores ser sua transformação em dimensão jurídica/normativa, estes humores, agora transformados em leggi et ordini, retroagem sobre o momento factual/político na forma de regulação das relações conflituais próprias a este momento. Quando não existem semelhantes mecanismos legais capazes de dar vazão aos humores, o resultado pode ser catastrófico. É o que Maquiavel lembra ao comparar duas situações: uma na qual existem mecanismos de desafogo - Roma com Coriolano - e outra na qual não existem - Florença com Francesco Valori e Piero Soderini. Na primeira "foi possível eliminar todos os males que poderiam advir do governo por uma autoridade privada" (Discursos I,7:II). Já na última, por não existir "uma ordenação capaz de desafogar os humores malignos que nascem nos homens sem o emprego de modos extraordinários" (Discursos I,7:I7), resultou em um "enfrentamento com armas" (com Valori) e numa "invasão do exército espanhol" (com Soderini). Quando na estrutura jurídica de um ordenamento político não houver a previsão de mecanismos de desafogo, a consequência inevitável é levar a vida política à destruição.

A análise do modo como se dá a relação entre grandes e povo - como uma dinâmica de scontrolencontro - mostra, segundo Del Lucchese (2015, p. Io), "que o poder constituinte pode ser mantido como um poder vivo unicamente aceitando o seu terreno totalmente conflituoso dentro das duas dimensões - política e jurídica - e pela renúncia à separação entre a sua gênese e seu desenvolvimento histórico". Isso também implica em renunciar à ilusão de uma vontade homogênea, ou da utopia da representação perfeita; ou seja, à ideia de que uma parte é constituinte quando pode legitimamente reivindicar a personificação da totalidade, representando-a na unidade da nova ordem soberana. A parte é, para Maquiavel, um humor entre outros humores. Por isso, qualquer ideia de representação da totalidade social fica excluída.

Esta afirmação pode soar paradoxal na medida em que o humor do povo — seu desejo de liberdade - é sempre universal (isso é verdadeiro, exceto na figura de povo como facção, na qual o povo substitui o desejo de liberdade pelo desejo de bens e cargos). O desejo de liberdade que anima ao povo é

23 Esta ideia pode ser lida, também, em Discursos I,I8:22, quando Maquiavel, examinando as diferentes maneiras pelas quais uma cidade pode enfrentar a corrupção, escreve: "portanto, para que Roma se mantivesse livre naquele estado de corrupção, era necessário que, assim como ao longo de suga vida criara novas leggi, também tivesse criado novas ordini [...]". Significa: para Maquiavel leggi et ordini são modos ordinários de conservação de um libero vivero. 
desejo de uma parte, mas que se materializa unicamente sob a condição de valer para todos. É por isso que se pode dizer que o povo - e somente ele pode afirmar a liberdade própria (o humor que lhe é próprio) como liberdade comum. É nesse sentido que a "parcialidade" povo se distingue radicalmente da "parcialidade" grandes. Estes, porque movidos pelo desejo de dominar e comandar, são a parte cuja parcialidade é impossível de tornar-se universal, pois não tem como ser levada a efeito sem excluir a outra parte (o povo): os grandes podem realizar o humor que lhe é próprio unicamente impedindo radicalmente ao povo o gozo tanto do humor dos grandes, quanto o daquele que é próprio ao povo.

No entanto, ainda que o humor do povo - enquanto desejo de liberdade - seja, por definiçãao, universal, nem por isso pode reivindicar a representação do todo social. ${ }^{24} \mathrm{O}$ desejo popular de liberdade permanece desejo de uma parte. É a isso, precisamente, que Maquiavel chama a atenção no Livro III de História de Florença quando descreve a história da cidade como marcada por divisões sucessivas das partes. Quando uma das partes da cidade - o povo - tenta unificar a cidade sob sua única autoridade, produz na verdade uma nova divisão interna: a divisão entre povo e plebe. Significa dizer, quando o humor do povo pretende representar a totalidade social, em vez de instituir o "reino da liberdade", como dirá mais tarde Marx, introduz uma nova forma de divisão na própria parte e passa da luta pela liberdade ao exercício da dominação. É por isso que entendemos que a instituição de um vivero libero requer uma mescla de confronto e cooperação, de modo que o conflito entre as partes produza ordenamentos que impeçam às partes de apropriar-se do poder. Isso é possível somente na medida em que reconhecermos o povo como potência instituinte que se exerce na resistência em seu confronto com os grandes, mas que jamais se "institucionaliza" na forma de exercício das funções de governo.

\section{Considerações finais}

No pensamento de Maquiavel podemos falar de um "momento instituinte"25

24 Visentin (em comentário à versão inicial deste artigo) faz a propósito dessa questão uma observação importante: "o universalismo da liberdade maquiaveliana não se exprime politicamente como 'liberdade de todos'; é um universalismo meta-político, que existe na política somente como tensão, mas pode realizar-se somente fora da política”.

25 Adverse (em comentário livre à versão preliminar deste texto enviado por e-mail) é do entendimento de que o uso do conceito "poder constituinte" para pensar as implicações da ideia de conflito em Maquiavel é fonte de inúmeros problemas. Entre outros, destaca os seguintes. Primeiro, de que não teria como "ser desvencilhado da ideia de uma comunidade anterior à formação do corpo político", de "pressupor um povo antes da 
como processo que liga a origem política à vida jurídica do Estado. Neste sentido, representa a dimensão inevitável (e até mesmo desejável) do conflito, da luta pela liberdade, que reúne o político (o momento factual) à dimensão jurídica (o momento normativo). Para Maquiavel, o conflito entre grandes e povo é um processo de resistência recíproca. Neste processo, a força criativa (inovadora e de produção legislativo-institucional) do povo não é mais absoluta do que a resistência dos grandes o é em relação à mudança que esta invenção legislativa implica. Não se trata, porém, de uma oposição que ignora qualquer relação interna recíproca entre as duas potências. O povo, como potência instituinte, é uma força viva, ativa, que está presente tanto no momento factual/político quanto no jurídico/normativo. A paradoxalidade desta afirmação se dissolve se lembrarmos que o resultado do confronto de grandes e povo tem em vista sua institucionalidade (jurídica/normativa) e, por sua vez, esta institucionalidade - na forma de leggi et ordini - retroage sobre o plano factual/político no sentido de criar e conservar um vivere libero et civile ao dar vazão aos humores que estão na origem da criação dos mecanismos legais.

Por esta razão, "instituído" é compreendido por Maquiavel não como algo "cristalizado" sob um aparato jurídico-político, mas como algo que permanentemente coloca em movimento a lei graças à natureza constitutiva do conflito dentro da vida política revelando, assim, a contingência e relatividade dos princípios e normas estabelecidas. É por esta razão que em Maquiavel não existe ainda uma concepção de "poder constituído" na acepção que tomará na modernidade tardia, pois a lei está sempre por se fazer, está em contínuo processo de transformação segundo as circunstâncias, de sorte que o "constituído" será, talvez, melhor compreendido como "em processo de instituição". Isso mostra que a visão positiva do conflito político por parte de Maquiavel pode ser compreendida como uma tentativa de explicar a influência recíproca entre o factual e o jurídico, entre os momentos instituinte e instituído, sem assumir a necessidade de que o primeiro seja neutralizado pelo último, como ocorre nas teorias contratualistas modernas. Essa ideia, mantidas as ressalvas acima, nos aproxima da posição de Del Lucchese (20I5, p. 5): "por meio de Maquiavel podemos apreender o poder constituinte como

cidade"; segundo, "a identificação do povo com o poder constituinte significaria atribuir-lhe uma universalidade"; terceiro, "se o povo é o poder constituinte, o que seriam os grandes? Seriam meramente auxiliares do universal?” Adverse tem razão ao chamar a atenção ao anacronismo do uso da expressão "poder constituinte" referido a Maquiavel. Por isso nos decidimos a falar de povo unicamente como "potência instituinte", entendendo "povo" não como unidade homogênea, e sim como um pluriforme aparecimento na cena pública. No entanto, em relação à segunda e terceira objeções, ponderamos que "povo" é, para Maquiavel, sempre parte e que, embora o florentino se refira a ele como il universale, esta universalidade não está em uma suposta capacidade de representação homogênea do todo, e sim no objeto de seu desejo (a liberdade). 
uma potência conflituosa que precede, dirige e excede o poder constituído, não indo além da lei, mas ocupando seu centro e transformando a sua natureza”. Ao mostrar que o momento instituinte não pode ser considerado como inteiramente anterior ao momento instituído e, portanto, totalmente exterior e alheio a este, faz aparecer o "poder constituinte" como a força simultaneamente ordinária e extraordinária que transforma continuamente a configuração institucional.

\section{Agradecimentos:}

Um agradecimento especial a Stefano Visentin, meu supervisor no estágio pósdoutoral na Universidade de Urbino, Itália (setembro 20I7- agosto 20I8), pelo acompanhamento crítico de minhas reflexóes.

Meu agradecimento também aos colegas do GT da ANPOF, aos quais enviei uma primeira versão deste texto e dos quais recebi conselhos e críticas pelas quais sou muito grato, em particular Helton Adverse, Sérgio Cardoso e Stefano Visentin. Naturalmente, continuo o único responsável pelos erros remanescentes, alguns, talvez, considerando as observaçôes registradas no rodapé deste trabalho, insanáveis!

\section{Referências}

Adverse, Helton (2007). "Maquiavel, a República e o Desejo de Liberdade", Trans Form $\backslash A c ̧ a \tilde{a}$, vol. 30, n. 2, p. 33-52.

Ames, José Luiz (2009). "Liberdade e Conflito: o confronto dos desejos como fundamento da ideia de liberdade em Maquiavel", Kriterion, n. II9, pp. 265-286.

Ames, José Luiz (2013). "Função do conflito sob um governo principesco: poder político e jogo de alianças em Maquiavel”, In Helton Adverse, Filosofia política no renascimento italiano, São Paulo: Annablume.

CARdoso, Sérgio (2015). "Em direção ao núcleo da 'obra Maquiavel': sobre a divisão civil e suas interpretações”, Discurso, vol. 45, n. 2, pp. 207-247.

Del Lucchese, Filippo (2017). "Machiavelli and constituent power: the revolutionary fundation of modern political thought", European Journal of Political Theory, vol. 16 (I), pp. 3-23.

De Vries, Hans (1957). Essai sur la Terminologie Constitutionnelle chez Machiavel ("Il Principe"), Amsterdã: Universidade de Amsterdã/Faculdade de Direito.

ErCole, Francesco (1929). Dal Comune al Principato - Saggi sulla storia del diritto pubblico del Rinascimento italiano, Florence: A. Vallecchi.

Frosini, Fabio (20IO). "E questa difficoltà è ragionevole: La perdita della libertà nei 'Discorsi' di Machiavelli", In Nicola Panichi (Ed.), Figure di 'servitù'e 'dominio' nella cultura filosofica europea tra Cinquecento e Seicento, Florence: Le Lettere. 
Gaille-Nikodimov, Marie (2004). Conflit civil et liberté: la politique machiavélienne entre histoire et médecine, Paris: Honoré Champion.

Lefort, Claude (1972). Le Travail de l'aeuvre Machiavel, Paris: Éditions Gallimard.

Lefort, Claude (1999). Desafios da escrita política, São Paulo: Discurso Editorial.

Machiavelli, Niccolò (200o). Discorsi sopra la prima Deca di Tito Livio, Introdução de Gennaro Sasso, preâmbulo e notas de Giorgio Inglese, Milano: Rizzoli Editore.

Machiavelli, Niccolò (1986). "Del modo di tratare i popoli della Valdichiana ribellati”, In Opere di Niccolò Machiavelli, v. 2, Torino: UTET.

Maquiavel, Nicolau (2007). História de Florença, trad. MF, São Paulo: Editora Martins Fontes.

Maquiavel, Nicolau (2009). O Príncipe (edição bilíngue), tradução e notas de José Antônio Martins, São Paulo: Hedra.

Pancera, Gabriel (20IO). Maquiavel entre repúblicas. Belo Horizonte: Editora UfMG.

Sfez, Gérald (1999). Machiavel, la politique du moindre mal. Paris: PUf.

Vatter, Miguel (2002). "Resistance and Legality: Arendt and Negri on Constituent Power”, Kairos: Revue de philosophie de l'Université de Toulouse, 20, pp. I9I-230.

Visentin, Stefano (20I5). "The Different Faces of the People: On Machiavelli's Political Topography”. In Filippo Del Lucchese; Fabio Frosini; Vittorio Morfino. The Radical Machiavelli: Politics, Philosophy and Language. Leinden/Boston: Brill. 